\title{
Reimagining the Indian Political Set-Up:A Political Branding Outlook
}

\author{
Dr Amit Kumar \\ Assistant Professor \\ Institute of Business Management \\ GLA University \\ Mathura, Uttar Pradesh \\ amit.kumar@gla.ac.in \\ +91-9568749565
}

\begin{abstract}
Politics is one area which the layman might not associate with the field of branding but with time this aspect of modern-day democracy has become synonymous with branding. Jevons (2005) is of the view that branding is flexible enough to include the realms of politics. The consumercitizen concept is a step in this very direction. Today's voter behaves more on the lines of a consumer who needs to convinced to buy into (read vote) the brand promises (read election manifesto and promises made during campaigning) put up by various political brands. Just like there are two aspects of a brand, successful and failed, political branding is no exception to the same. Modern times have seen the rise of many a political brands some of whom have had an ardent following while others have been shunned by the electorate for their disconnect with the voter. The western democracies such as US and UK are replete with political brands which have proven their mettle (or faded into oblivion) during various elections. However, the same has came to fore only in the past few years in India thanks to the information revolution. No other election witnessed more significantly the concept of political branding as did the last two general elections of 2014 and 2019. The concept of political branding and political participation have shown quite strong relationship between them in those countries where it is applicable. Through this paper, the author has attempted to establish a relationship between political branding and political participation along with what characterizes the successful making of a political brand in a conceptual way.
\end{abstract}

Key words: Political Branding, Political Participation, Political Marketing, Election.

\section{Introduction}

Brands have made their presence felt in every walk of life. They have been a part and parcel of our daily scheme of things for much longer then we could imagine. As Danesi (2006) rightly points out that brands have been around us since "the dawn of history" in the form of trademarks. Danesi (2006) further elaborates that if the identification of a product is aided by visual schematics, then it is the concept of branding at the fore.

The modern times are characterized by the rise of the concept of consumerism wherein the consumers are increasingly becoming aware of their rights and calling the shots thus deciding the fate of various organizations. This holds true for the political icons and parties which dominate the mindscape of voters. Consumer activism and branding have been hand in gloves with each 
other thus making it sensible as well as necessary for organization of various hues to respond timely and accurately to the consumers' inputs as well as feedback. Scammell (2007) is of similar view that the ascent of consumer awareness has been coupled with branding thus creating new paradigms. Scammell (2007) is also of the view that the contemporary field of branding has taken shape more on the lines of a theory wherein such diverse notions as nations, places, cities and politicians (focus of this research paper) have found resonance thus taking it to the next level. Scammell (2007) further opines that as time passes by, politicians are increasingly getting leveraged as brands thus extending their appeal. A politician who is more accessible, realistic, approachable, relatable and emanating hope would be considered to be a better brand as compared to its compatriots.

As we are well aware that sales is not the be all and end all of marketing. Rather it is a part of it. Likewise, Jevons (2005) is of the view that it is not only advertising that makes branding. Branding is much more than merely being associated with advertising, no matter how good and effective an advert is. At the same time, having a strong brand image is imperative for a political brand to succeed. Scammell (2007) takes it further and says that an impressive brand name is equally important, if not more, as is a good politician or outfit. Martin Luther King Jr. This name itself has got a certain click to it and even before one knows anything about the politician or his affiliations, the brand name does develop an aura around it thus making the consumer-citizen curious to know more about it.

Fetscherin et al. (2014) have talked about even during many early deliberations, brands were seen more as relationship partners above all else. They are of the view that human personalities and characteristics were seen as intertwined with brands. This does hold true in the case of political brands. The better voters are able to related with the political brand, the more are the prospects of it succeeding provided it lives up to the pre-voting expectations because the interesting aspect related to political branding is that they come with an expiration date (in India and UK 5 years, in US 4 years). In case of India sometimes even this gets curtailed in the form of mid-term elections owing to backtracking by coalition partners. This trend was particularly prevalent in the last years of the past century and early years of this century.

\section{Understanding Political Branding}

Political branding has been around for some time, especially in the western democracies. However, its presence has been felt substantially after the rise of information revolution which made it possible for the consumer-citizen to stay in touch with political outfits and leaders as and when they desired, more on the lines of round-the-clock. The scrutiny which the politicians face with regard to their manifestos, deeds, campaigns, post-selection works has become much higher. When it comes to defining political branding, it is the manifestation arising out of the perception developed towards a political outfit, leader, campaign, strategy, policies, and other related terms which define the existence of a political entity. This is done both with the help of material cues such as political rallies, buttons, bill boards, campaigns, public appearances, as well as immaterial hints such as belief, trust, relatedness, interest, awareness, curiosity, etc. Language, symbols, signs also play a crucial role in the formation and popularity of a political brand. It is for this reason that some political brands are more popular than others. 
With time, political branding has proven its worth and has been considered as a big business by such thinker like Jevons (2005) who credits this development to the popularity of this concept among the political leaders and organizations who have lapped it up with an open mindset as they came to understand the merit of it. Even the naysayers have accepted its efficacy and turned to it to revive their fortunes. Jevons (2005) further is of the view that the singularity related to consumers, which is normally associated with branding, has changed to a multiple scenario thanks to the advent of political branding in its realms. Further he says that the comprehensive way in which political campaigns are managed in today's political scenario essentially characterize the phenomenon of political branding. Speed, Butler, \& Collins (2015) are of a similar view. As per them, political branding has evolved as a multidisciplinary concept borrowing to varying extents from management, journalism, sociology and economics. This is so because campaigning is an economics-based activity whereas sociology does influence the way political brands behave in a certain way. Management is another arena which political branding touches because without management it would quite difficult to ensure the success of a political brand. And journalism is an arena which influences every politician in one way or the other. In that sense, political branding indeed touches multiple areas and in the process brings a layered approach towards the leaders and parties.

Chandler \& Owen (2002) talk about the cultural aspect related to political branding and are of the opinion that a good political brand should resonate with the electorate in the cultural sense so that they are on the same page and connect with each other. In this regard, they also opined that a successful political brand is one which has a charisma and the ability to pull the crowds to its rallies, speaks in their tongue and their minds. The rustic charm which leaders like Lalu Prasad Yadav, Mulayam Singh Yadav and Mamata Banerjee bring to the table plays a crucial role in making them popular among the masses. It is with this very perception that when national leaders visit such states where the vernacular is different from English or Hindi, they tend to speak or at least infuse a few sentences in the local language or dialect to develop an instant connect with the crowd. Similarly, Clifton et al. (2009) focus on the social aspect of a brand and proclaim that brands are being increasingly viewed as torchbearers of the social well-being. Thus, a political brand needs to focus upon good social deeds apart from making promises with regard to performance. This is so because today's consumer-citizen holds such political brands higher than others on the virtue of their societal commitments.

Williams (2000) talks about the reciprocal relationship which a political brand tends to develop with the electorate. This affects the way the electorate feel about the political brand. The stronger the relationship between them, the more influence a political brand wields over its rivals.

History is replete with examples (as is modern world) with examples which go on to prove that the best brands are those which are able to get their point across in the simplest possible way. People always prefer such brands which are easily differentiated from their rivals thus highlighting their superiority in the simplest possible manner. This trait of effective branding is particularly effective in the case of political branding, specifically in a democracy like India, where the political scenario is cluttered with umpteen choices thus confusing the consumercitizen making it quite difficult to choose one brand over the other.

It is in this context that Smith and French (2011) have given their finding on heuristics or 'mental shortcuts'. They are of the view that humans normally tend to avoid new learning as 
long as they are comfortable with the existing information. The political brands with which the voters develop an association are the ones with whom the consumer-citizen tends to stay no matter which all new developments take place in the political scenario. This association helps them to avoid complex situations wherein they need to decide on their political affinity for one political brand over the other. This very much holds true in the Indian political scenario where voters tend to vote en-masse and repeatedly for a particular political brand no matter what the scenario is. However, this tendency has changed with time but still plays a crucial role in the overall scheme of things. This builds upon the views of Scammell (2007) who was of the opinion that brands act as short cuts as the images, sounds (such as jingles), taglines associated with them help the consumer to identify with the brand instantaneously thus cutting through the clutter. An easily recallable political brand would definitely score above its compatriots even before the election campaign begins or the ballots are cast.

Neiheisel \& Niebler (2013) are of the opinion that having appealing party symbols, candidate logos, slogans, add to the political brand. At the same time, overtly usage of them leads to brand dilution and erodes brand value. Hence, the parties should exercise a bit of restraint when it comes to using their political brands because even the best brands can be victims of overexposure thus losing their novelty factor in the process.

Lees Marshment (2009), one of the leading thinkers in the arena of political branding, observes that when it comes to differentiating among various political outfits and leaders, political branding plays a crucial role as it provides the voters with enough cues to tell one leader or party from the other. Then there are others like Serazio (2015) who are of the view that with time political branding has matured as a concept and is more than just a mere differentiator among politicians or outfits. He is critical of the practices related to branding being used in the American political campaigns.

\section{Political Branding: The Indian Connect}

Seidman (2010) is of the view that a positive image, a strong following coupled with an uplifting message go in the making of a triumphant political brand. This is so because such a political brand makes the electorate hopeful, excited and feel good. Such was the scenario during the general election of 2014 in India initially and then again in 2019. The electorate rallied behind one political brand over all others and this resulted in an unprecedented mandate wherein a nonCongress party got a majority in the history of Indian politics, first in 2014 and then in 2019, and a single-party majority government was formed after three decades in 2014 and then again in 2019. Riding on the charisma of one political brand which outplayed and outweighed all its compatriots by such a huge margin that even the supporters were bewildered though they expected a fine performance but like a super brand, brand NaMo surpassed its own expectations thus making everyone else sit up and take notice not once but twice. Again, like a winning brand even before the results were declared or even when voting was going on, both the believers and detractors had a feeling that brand NaMo is going to outperform its compatriots by a big margin. This became possible due to the brand promise which the brand kept on projecting during all the rallies, talk shows, gatherings, on social platform, basically a $360^{\circ}$ approach towards brand engagement which was without a parallel in modern political history anywhere in the world.

What's more important to note here is the aspect that there was a consistency in the projection during the entire campaign in terms of brand performance, much like propagated by Creamer 
(2008) who talks about how a strong political brand should exhibit consistency in terms of its message as well as when it comes to fulfilling that brand promise in terms of brand performance. As per a report " $70 \%$ want Narendra Modi to be PM till 2024, 62\% happy with his performance" (2016) conducted by Centre for Media Studies and put up by one of the leading news channels of the country, Zee News, 70\% of the surveyed population wish to see Narendra Modi as PM till 2024 and $62 \%$ were happy with his performance. This survey was chosen for the present study for the simple reason that it was conducted somewhere in-between the first term of Narendra Modi Government which gave an understanding about how voters felt. Similar studies have been performed from time and time and every time brand NaMo triumphed its compatriots by a comfortable margin. Though the findings of these surveys include some negative reactions for the government but brand NaMo was still found as the favourite among the various political brands. It is for this reason that the incumbent government won the 2019 General Election comprehensively riding on the charisma of brand NaMo, getting 303 seats out of 541, a tally which it bettered from the 273 seats the party got in 2014. This is quite exceptional in the sense that no party or coalition in modern Indian politics, barring Indian National Congress (henceforth Congress/INC), the Grand Old Party of India and United Progressive Alliance, have been able to overcome the anti-incumbency factor in the past and even when they did, the tally went down as compared to the initial number of seats whereas Bharatiya Janata Party (henceforth BJP)-led National Democratic Alliance got more seats in the second outing thanks to the charisma of brand NaMo. Even when we talk about Congress coming back to power on multiple occasions in pre-coalition days, it primarily happened due to the personal pull of such strong political leaders like Jawahar Lal Nehru or Indira Gandhi more than anything else. However, BJP has not been able to replicate its success in the state elections (most recent example being the state assembly elections in Delhi held in February 2020 which took place a mere 9 months after the general election of May 2019. During the Lok Sabha election, BJP swept 7 out of 7 seats as people voted, en-masse, for brand NaMo not much concerned with who was representing the party at which seat. However, when it came to the state assembly election, the same voters chose a regional political brand Arvind Kejriwal and gave his party the Aam Aadmi Party, a huge mandate of 62 seats out of 70 seats in the Delhi Assembly "2020 Delhi Legislative Assembly election" (n.d.). As per Bhatnagar, G. V. (2020, Feb 13) in the last Lok Sabha election of 2019, the BJP polled $56.86 \%$ of valid votes in Delhi, and in the recent assembly election of 2020, AAP ended up with $53.57 \%$ vote share. Here it would be pertinent to mention that even brand Kejriwal has gone from strength to strength as his party got a stupendous 67 out of 70 seats in the 2015 state assembly election which they very well carried forward in 2020). This goes on to prove that delivering on brand promise leads to better acceptability once a political brand is in power. The cases of the two political brands, brand NaMo at national level and brand Kejriwal at state level (Delhi) could be mentioned in this regard.

As has been evident in the past few elections in India, same set of voters tend to vote differently in general election as compared to state elections. This has got much do with their identification with a popular figure at the central level thus convincing them to root for it. On the other hand, they find it more sensible to vote for a local and popular political entity when it comes to state elections. This phenomenon was seen in Jharkhand and Delhi recently as the voters of these two states voted different parties and coalitions in general election. "2019 Indian general election in Jharkhand" (n.d.) indicates that Jharkhand which saw the first single-party majority government in its brief history (it was carved out of Bihar in 2000) only in 2014 when BJP won the mandate 
for the state assembly riding on the Modi wave, only to be dislodged by the Congree-Jharkhand Mukti Morcha Alliance in November 2019 despite BJP and its ally winning 12 out of the 14 Lok Sabha seats in the general election held in May 2019. This assumes significance because the elections to these two states were held close on the heels of the general election. Then there are the voters of Haryana, and to an extent Maharashtra, who voted for almost the same party, although not with the same exuberance, thanks to the strong image of brand NaMo who voted for it both at the centre and state elections. But in both the states the party fell short of majority mark thus leading to formation of different governments for both the states. While BJP was able to form government in Haryana, albeit by combining with one of its rivals; in Maharashtra, the prepoll alliance between BJP and its regional ally Shiv Sena was broken after result and Shiv Sena formed the government in alliance with Congress and another regional party Nationalist Congress Party.

Amidst all this, at the other end of the spectrum, stand the voters of such states as West Bengal, Tamil Nadu, Andhra Pradesh, Telangana and Odisha who vote for the regional political brands no matter whether it is the general election or state election. In fact, in the simultaneous elections which took place in Andhra Pradesh for both the Lok Sabha and State Assembly, the regional heavyweight YSR-Congress, under the leadership of Y S Jagan Mohan Reddy, got 22 out of 25 seats as well as formed the state government be securing 151 out of 175 seats in the state assembly "Elections in Andhra Pradesh" (n.d.). Likewise, in Odisha, where the general and state assembly elections took place simultaneously, the Biju Janata Dal, under the leadership of Naveen Patnaik, formed the state government by securing 112 seats out of 146 and a respectable 12 out of 21 seats in the Lok Sabha election "Elections in Odisha 2019” (n.d.).

In fact, such has been the charisma and pull of regional political brands as Naveen Patnaik of Biju Janata Dal and K Chandrashekhar Rao of Telangana Rashtra Samiti that they were voted back to power for a consecutive term in the respective state elections of Odisha (Naveen Patnaik has been the CM for five consecutive terms) and Telangana. Late J Jayalalitha, who was popularly known as Amma by her followers, bucked the anti-incumbency wave in 2016 and formed back-to-back governments in the state of Tamil Nadu, a first time in state politics in the last three decades. How strong was the pull of this regional political brand can be understood from the drubbing which her party AIADMK got in the Lok Sabha election of 2019, winning a solitary seat, as compared to the 37 seats, the third highest tally after BJP and INC, both national parties; her party got in the 2014 general election when she was alive. It can be well contrasted again with the performance of its rival party DMK which got no seats in 2014 general election but emerged as the third-highest party in the country in terms of seats in the Lok Sabha election of 2019 when it got 24 seats "Seventeenth Lok Sabha" (n.d.). In the absence of the charisma of Late J Jayalalitha, AIADMK failed to appeal to its core vote base and this fact was utilized by its rival party DMK. A peculiar case would be of brand Nitish Kumar of Janata Dal United in Bihar who has been at the helm of affairs by becoming the CM of the state for the first time in 2005 and having remained so for the past fifteen years thus showing his pull in the regional political landscape. However, in-between, he has jumped the ship many times as far as forming a winning alliance in the state is concerned, wherein he tied up with BJP on several occasions and also with his arch-nemesis Lalu Prasad Yadav's Party Rashtriya Janata Dal and Congress as per the situation. Presently, he is running his government in collaboration with BJP "Nitish Kumar" (n.d.). The pull of such brands as brand Jayalalitha, brand Naveen Patnaik, brand KCR and brand 
Mamata is much stronger as they have proven their mettle time and again no matter whether the battle field is a central election or state one, no matter whether they are fighting for re-election or first time.

White and de Chernatony (2011) observe that those political brands who don't fulfil the pre-poll promises are shown the door whenever next elections take place. They get greatly devalued and suffer. At the same time, today's voters have attained such maturity that they are more than willing to give a second, a third chance to a political brand in whom they trust even though it has fallen short of its promises based on their overall experience with that brand. This is not to say that anti-incumbency has become a thing of past. However the voter of today has become more pragmatic and is not easily swayed by petty benefits in the lead up to the election and value development more than anything else. Trust plays a very significant role in the success or failure (arising due to the lack of it) of a political brand.

In the past few years, regional political brands in Indian states like Mamata Banerjee, Late $\mathbf{J}$ Jayalalitha, Naveen Patnaik, KC Rao have proved that people are willing to give second/multiple chance/s provided they see the merit in the same even though the political brand has suffered a few setbacks during its previous tenure. In this context, Needham's (2006) concept of 'repeat buy' would make an appropriate and relevant reference. He puts up an interesting analogy wherein he compares an incumbent, who is seeking a re-election, to a product which is up for rebuying based on the past experience of the customer. The failure to live up to the expectations of the consumer-citizen in the preceding term would definitely dent the chances of re-election much like a bad product being unsubscribed from the wish-list of its repeat buyers.

\section{The Lok Sabha Elections of 2014 and 2019}

India witnessed the biggest election exercise in the history of mankind to elect the seventeenth Lok Sabha. According to the EC data, almost 603 million people -- more than South America's population -- of India's 900 million eligible voters exercised their franchise in this election to elect the fifteenth prime minister of the Republic of India. This election was historic in many aspects. The above quoted number becomes further significant in the light of the fact that the last general election witnessed a record percentage, an all-time high of 67.4\% "2019 Indian general election" (n.d.). The polls broke the record of 66.4\% polling as observed during 2014 general election by $1 \%$, and that too with an increased electorate of 85 million (in 2014, 814 million voters were eligible to vote) "2014 Indian general election" (n.d.), which was held in the background of anti-incumbency factor for United Progressive Alliance as well as the change narrative of brand NaMo. Interestingly, the next highest poll percentage $64 \%$ was recorded in 1984-85 when the elections were held in an emotionally surcharged atmosphere following the assassination of the then PM Indira Gandhi. However, no such factor was prevalent during either of the last two general elections still voters came in droves to vote. The development plank, relatedness, humble background, talks of inclusive growth, self-reliant economy, women empowerment, power to the downtrodden sections of the society were some of the issues on which brand NaMo fought the election first in 2014 and then in 2019. It would be imperative to mention that the 2019 general election was having in its backdrop the Pulwama attack which killed CRPF personnel after which the Narendra Modi government, showing its decisive nature, carried out the Balakot strikes thus finding frequent mentions in the lead-up to the election making national security a credible plank for the National Democratic Alliance pitching for re- 
election. Welfare schemes and fulfillment of the narrative also came to the fore when voters casted their votes in the 2019 general election. The voter turnout of $58.2 \%$ in the 2009 general election was indeed on the lower side if one looks at the voter trends of 2014 and 2019 marking a gap of almost $8-9 \%$ in the last two general elections.

To score the point further home, about 140 million more people turned up at polling stations as compared to the general elections in 2009. This is about 40 million more than the total number of new voters -- 100 million -- added to the electoral rolls in the past five years. Majority of these additional 40 million voters were either youth or female or both. As per Tiwari, S. (2019, Feb 20), 45 million new voters became eligible to vote in 2019 as compared to 2014 thus enhancing the voter list by almost $5 \%$ in $2019.43 \%$ of the total Lok Sabha members are elected from the five states of Bihar, West Bengal, Rajasthan, Maharashtra and Uttar Pradesh. These five states were the ones where maximum of the first-time voters of 2019 were elected and BJP and its NDA allies were the first choice in four of these five states. BJP came a close second in West Bengal in 2019, a much improved tally as compared to 2014. In effect, NDA consolidated its lead in all the four major states and bettered its performance in the fifth one.

What caused this steep increase in the voter turnout in 2014 as compared to 2009 and then more or less stabilized in 2019? More importantly which segments of the society played their part in it for the same are questions which need to be answered. This research paper delves on this issue and comes out with analyses which readers would be able to relate with. The role of political branding in the same is explored too and related with it.

Many experts believe that propelled by the high octane poll campaign by leaders of all parties, women and youth registered their highest ever show in the last two general elections. This is one of the aspects for sure which ensured higher turnout of the voters. There are different aspects related to it which would come up in further discussion.

The role of social media during the last two general elections of 2014 and 2019 is something which is worthy of mentioning and how it influenced participatory tendencies across various age groups, notably among the first time voters. Social media came into prominence in a political event for the first time during the 2008 Presidential election in USA, which Metzgar \& Maruggi (2009) term as the first social media election The Obama campaign successfully harnessed it and repeated its feat in 2012. By then, politicians across the globe understood the might of it. The 2012 and 2016 Presidential elections in USA, the 2014 and 2019 elections in India were contested as much (if not more) in the virtual world as they were in the physical world. Seidman (2010) is of the view that television plays a prominent role in politics. This holds true despite the onslaught of online media and in such countries like India where internet is not used by majority of the population. As per Mehta, N. (2019, Dec 27), Internet users in India went up by eight times between May 2014 (65.3 million) and May 2019 (581.51 million). Estimates vary about how many of these users were active, but most accounts agree that by 2019, about half of India's voting population now had access to information avenues in ways that were simply not possible earlier. By May 2019, roughly one-third of Indians had access to Facebook (up from 9\% in 2014), Whatsapp and YouTube. 
The political brand which made its presence felt the most all along during the election was brand NaMo by a huge margin.

\section{Increased Political Participation: Rise and Rise of Brand Modi}

The moment one talks about the increased participation in the last two general elections, antiincumbency is the obvious notion which comes into picture in context of 2014. However, the reality may be not as apparent as perceived. The detractors of brand NaMo had the tendency of dismissing its role in the success of its party as well as increased participation and attributed the results mostly to the anti-incumbency effect in 2014. One very pertinent observation in this regard has been provided by Sanjay Kumar, Director of the Centre for the Study of Developing Societies (CSDS), under the heading of National Election Studies. "I don't know how this idea that high turnout is associated with anti-incumbency has persisted from generation to generation," he says. "This relationship has never existed." To prove his point, he talks about the last 30 assembly elections. 24 of these saw higher voter turnouts as compared to the preceding ones. Out of these 24 , there were 12 which voted the incumbent back to power. On the other hand, 12 didn't. Thus it rendered this logic inconclusive that anti-incumbency leads to increased participation in a political event (Rukmani, S. 2014, May 14).

It then leads to the obvious question, what was responsible for the high turnout as witnessed during this election? More importantly, when one talks about the 2019 general election, antiincumbency couldn't be even pointed out as it was brand NaMo which bettered its performance as compared to 2014 and BJP was voted back to power. Such has been the dominance

Brand NaMo made its presence felt across various platforms, both physical and online. Narendra Modi travelled close to $300 \mathrm{~K}$ kms addressing 500+ rallies, unprecedented in the history of Indian politics in 2014. Even after becoming PM, he campaigned extensively in 2019 when he travelled almost 130K kms and addressed 140+ rallies. Although the campaign of 2019 was on the lower side as compared to 2014, still this was much higher than the campaign by his closest rival Rahul Gandhi who travelled $120 \mathrm{~K}$ kms and addressed $110+$ rallies. His appeal, presence on various media platforms with consistency in the message (Abki Baar, Modi Sarkaar in 2014 and Sabka Saath, Sabka Vikaas \& Modi hai to Mumkin hai in 2019), relatedness, humble background (from tea seller to four-times CM to the next PM), experience (four-time serving CM with a tenure running into a decade-and-a-half and five years as PM), commendability (the Gujarat Model of Development and many milestones during the first tenure as PM) added to the aura of brand NaMo during the election. Not only this, brand NaMo dominated the virtual landscape as well in the lead-up to the election becoming the second-most popular politician in the world just behind brand Obama during the 2014 general election, the same brand whose success inspired Narendra Modi to lap up to social media in a big way and brand Trump during the 2019 general election. Presently, he is having close to 44.6 million 'likes' on his official facebook page and 53.1 million followers on twitter. He has got his own website narendramodi.in apart from the official websites of PMO and party. More importantly, he is not only present on the social websites but also interacts with the users asking them for suggestions and listening to their views and complaints thus making political participation much more meaningful and relevant than the traditional modes of political participation. Even the various ministries of the government have taken the social media route for first-hand interaction keeping in view its effectiveness. More importantly, one needs to keep this fact in mind that a social media user doesn't necessarily need 
to be registered as a voter to participate in the political activities as is the case with the traditional mode of participation. Again, this is not to say that the conventional mode of participation, namely getting registered and turning up on the day of voting, is losing its sheen. Far from it, as the trend shown above, the last general election saw the highest ever turnout in history of India.

When one argues whether it was the party or the leader who won the mandate, here is the bottom-line. It is not as if BJP contested the general election for the first time. Rather it was contesting it under the effect of brand NaMo for the first time in 2014 and then again in 2019 and the difference was more than telling. Of the possible 543 seats up for grabs, BJP won 282, 10 more than the half-way mark necessary for forming the government in 2014 and only bettered in 2019 by winning 303 seats, a feat which was not achieved by any party other than Congress till now. INC won majority on its own for the last time three decades ago riding on the sympathy wave in the aftermath of assassination of Lt. Indira Gandhi. In fact, all the pre-poll talks about equations arising after the elections were doused in the TsNaMo (as famously proclaimed by a leading daily of the nation). BJP even didn't need the support of its alliance partners of NDA. BJP+ stood at a mammoth 331 in 2014 and 358 in 2019, an impressive tally by any benchmark. However, Narendra Modi was criticized for forming a single-party government with the least vote percentage of $31 \%$ in independent India. In 2019, this anomaly was also corrected when Narendra Modi became the only prime minister in the history of Indian politics to have bettered the seat tally of his party BJP from 282 to 303 as well as the percentage of votes polled by BJP from $31 \%$ to $37 \%$. The self-reliance on brand NaMo was well reflected in the choice of ministers for various departments in both the governments. Narendra Modi handpicked those whom he felt right for that post, not bound by any alliance dharma as was the case during the coalition-era politics. It ruffled many a feathers but he was unperturbed.

A good political brand is one which apart from being successful, puts all the other brands on to the back foot. This is precisely what happened in the case of brand NaMo and others as well. The impact of brand NaMo was felt by such regional bigwigs like SP, BSP, TMC, BJD. Despite having the third-largest vote share of around $4.1 \%$ after BJP (31\%) and INC (19\%) in 2014, BSP didn't win a single seat. However, when it tied up with its arch-nemesis SP in the lead-up to the general election, it in itself was an indicator of the might which BJP had in the state of Uttar Pradesh, which sends the highest number of MPs (80) to the Lok Sabha. Here it would be pertinent to highlight the performance of a regional party like Janata Dal United in Bihar which fought the Lok Sabha election against brand NaMo in 2014 and won merely 2 seats and in collaboration with brand NaMo in 2019 and won 16 seats. Another case of contrast is that of Telugu Desam Party of Andhra Pradesh which contested the 2014 general election as an ally of NDA and won 15 seats whereas in 2019 when the party fought the general election against brand $\mathrm{NaMo}$, it got only 3 seats. Although the pull of a strong regional political brand Jaganmohan Reddy (his party YSR-Congress won 22 seats, fourth-highest in the country) was much responsible for the dismal performance of TDP in Andhra Pradesh, it can be said that moving away from a strong national political brand like brand NaMo added to the woes of the regional party. In the 2014 general election, when AIADMK won 37 seats, third-highest tally in the country after BJP and Congress, one news channel aptly had a headline, "Election Results 2014: Jayalalithaa Has a Whopping 37 Seats That Narendra Modi Does Not Need" (Bhattacharya, S. 2014, May 16). In pre-Modi era, this could very well have been the difference between formation or non-formation of government at the central level in the era of coalition politics. It is not 
without a reason that one of the leading experts called this as the 'Death of Kingmaker', as had been the tradition where regional players played a crucial role in the formation of the central government and dictated their terms in the process. Well, not anymore.

\section{Concluding Remarks}

To what extent brand NaMo has lived up to the expectations of the electorate in the past six years since it has come to power, first in 2014 and then again 2019 with even better seat tally, is beyond the scope of this research paper though the general acceptance towards brand NaMo (as mentioned earlier) is still very much there. This is well reflected in the outcome of both the general elections. At the same time, his critics argue that brand NaMo might have taken a beating in the light of the numerous state assembly elections results which have not gone his way thus highlighting a peculiar trend of same set of voters voting differently during central and state assembly elections, preferring a strong local political brand over the charisma of brand NaMo. It should be well kept in consideration that there are hardly any instances of a political brand enjoying the same popularity after being in the office for a certain period of time. The popularity of brand Obama dipped during his second term as compared to the pre-poll ratings enjoyed by him. It is quite a difficult task for a political brand to live up to the expectations of the electorate who have reposed their trust on it once it assumes office because of the harsh realities of realpolitik. The lofty goals set during the campaigning and mentioned in the manifesto go for a toss many a times. In the light of all this, it is indeed an amazing achievement for brand NaMo to have been voted back to power, the second mandate being better, both in terms of number of seats as well as vote share, which goes on to prove the might of brand NaMo as compared to its competitors. Another worthy mention which was the outcome of this research paper was the fact that indeed a strong political brand leads to better voter turnout which was evident both in 2014 and then again in 2019 when the overall poll percentage touched 66 and $67 \%$ respectively and in both the elections a strong political brand at the national level acted as the catalyst for the voters to turn up at the polling booths. This becomes stark when one takes into consideration the polling percentage of $58 \%$ which was registered during the 2009 general election.

\section{References:}

1. 2014 Indian general election (n.d.) retrieved from https://en.wikipedia.org/wiki/2014_Indian_general_election

2. 2019 Indian general election in Jharkhand (n.d.) retrieved from https://en.wikipedia.org/wiki/2019_Indian_general_election_in_Jharkhand

3. 2019 Indian general election (n.d.) retrieved from https://en.wikipedia.org/wiki/2019_Indian_general_election

4. 2020 Delhi Legislative Assembly election (n.d.) retrieved from https://en.wikipedia.org/wiki/2020_Delhi_Legislative_Assembly_election

5. 70\% want Narendra Modi to be PM till 2024, 62\% happy with his performance: Survey (May 02, 2016). Retrieved from http://www.daijiworld.com/news/newsDisplay.aspx?newsID=392701 
6. Bhatnagar, G. V. (2020, Feb 13) AAP's Big Victory: Here's What the Polling Data from Delhi Reveals About Modi vs Kejriwal retrieved from https://thewire.in/politics/delhielection-aap-polling-data

7. Bhattacharya, S. (2014, May 16) Election Results 2014: Jayalalithaa Has a Whopping 37 Seats That Narendra Modi Does Not Need retrieved from https://www.ndtv.com/elections-news/election-results-2014-jayalalithaa-has-a-whopping37-seats-that-narendra-modi-does-not-need-562235

8. Chandler, J. Owen, M. (2002). Introduction: the nature of brands 2-24. Developing Brandswith Qualitative Market Research. Thousand Oaks, California.

9. Clifton, R. et al. (2009). Brands and branding. New York: Bloomberg Press.

10. Creamer, M. (2008). Barack Obama and the audacity of marketing. Advertising Age. 79(42).1-55.

11. Danesi, M. (2006). Brands. New York and London: Routledge Press.

12. Elections in Andhra Pradesh (n.d.) retrieved from https://en.wikipedia.org/wiki/Elections_in_Andhra_Pradesh

13. Elections in Odisha 2019 (n.d.) retrieved from https://en.wikipedia.org/wiki/Elections_in_Odisha\#2019

14. Fetscherin, M., Boulanger, M., Gonçalves Filho, C., \& Quiroga Souki, G. (2014). The effect of product category on consumer brand relationships. Journal of Product \& Brand Management, 23(2), 78-89.

15. Gertner, D. (2011). A (tentative) meta-analysis of the 'place marketing' and 'place branding' literature. Journal of Brand Management, 19(2), 112-131.

16. Jevons, C. (2005). "Names, brands, branding: beyond the signs, symbols, products and services." Journal of Product \& Brand Management, Vol. 14 Iss: 2, pp.117 118

17. Lees-Marshment, J. (2009). Political marketing: Principles and applications. New York: Routledge.

18. Mehta, N. (2019, Dec 27) Digital Politics in India's 2019 General Elections retrieved from https://www.epw.in/engage/article/digital-politics-indias-2019-generalelections?0=ip_login_no_cache\%3D47fc28b169930da44f23c38e22c0971e

19. Metzgar, E., \& Maruggi, A. (2009). Social Media and the 2008 US Presidential Election. Journal of New Communications Research, 4(1).

20. Needham, C. (2006). Brands and political loyalty. Journal of Brand Management, 13(3): pp. 178-187.

21. Neiheisel, J. R., \& Niebler, S. (2013). The use of party brand labels in congressional election campaigns. Legislative Studies Quarterly, 38(3), 377-403.

22. Nitish Kumar (n.d.) retrieved from https://en.wikipedia.org/wiki/Nitish_Kumar

23. Rukmani, S. (2014, May 14) Not how many, but who voted made the difference. Retrieved from https://www.thehindu.com/opinion/op-ed/not-how-many-but-who-votedmade-the-difference/article6022959.ece

24. Scammell, M. (2007). Political Brands and Consumer Citizens: The Rebranding of Tony Blair, The ANNALS of the American Academy of Political and Social Science. 611 (1), 176-192. DOI: $10.1177 / 0002716206299149$

25. Seventeenth Lok Sabha (n.d.) retrieved from https://loksabha.nic.in/members/PartyWiseStatisticalList.aspx

26. Seidman, S. A. (2010). Barack Obama's 2008 campaign for the US presidency and visual design. Journal of Visual Literacy, 29(1), 1-27. 
27. Serazio, M. (2015). Branding politics: Emotion, authenticity, and the marketing culture of American political communication. Journal of Consumer Culture, 1469540515586868.

28. Smith, G., \& French, A. (2011). The political brand: A consumer perspective. In P.R. Baines (Ed.), Political Marketing (Vols. 1-3) (pp. 1-18). London: SAGE.

29. Speed, R., Butler, P., \& Collins, N. (2015). Human Branding in Political Marketing: Applying Contemporary Branding Thought to Political Parties and their Leaders. Journal of Political Marketing, 14, 129-151.

30. Tiwari, S. (2019, Feb 20) Data check: 45 million new, young voters could play a key role in 2019 elections retrieved from https://scroll.in/article/913411/data-check-45-millionnew-young-voters-could-play-a-key-role-in-2019-elections

31. White, J., \& de Chernatony, L. (2011). New Labour: A study of the creation, development and demise of a political brand. In P.R. Baines (Ed.), Political marketing (Vols. 1-3) (pp. 151-156). London: SAGE.

32. Williams, G. (2000). Branded? London: V\&A Publications. 